\title{
Comparative Analysis of the Anatomy of Two Populations of Red-Root Amaranth (Amaranthus retroflexus L.)
}

\author{
Sava Vrbničanin ${ }^{1^{*}}$, Lidija Stefanović ${ }^{2}$, Dragana Božić ${ }^{1}$, Marija Sarić ${ }^{1}$ and \\ Radenko Radošević ${ }^{1}$ \\ ${ }^{1}$ University of Belgrade, Faculty of Agriculture, 11080 Belgrade, Nemanjina 6, Serbia \\ (sava@agrif.bg.ac.rs) \\ ${ }^{2}$ Maize Research Institute Zemun Polje, 11080 Belgrade, Slobodana Bajića 1, Serbia
}

\section{SUMMARY}

The anatomy of stems and leaves of two populations of the weed species Amaranthus retroflexus $\mathrm{L}$. (red-root amaranth) (pop. AMARE $E_{1}$ having green stems covered in sparse hairs and pop. AMARE 2 with green but notably dense stem hairs) was analysed in order better to understand the uptake and translocation of herbicides that could be indicative of the species' evolving resistance to herbicides. Samples of the two populations (AMARE and $\mathrm{AMARE}_{2}$ ) were collected from arable land of the Institute of Maize Research at Zemun Polje in 2006. Sampling was performed at the stage of full vegetative growth of plants. Permanent microscoping preparations were made to measure and analyze elements of the anatomy of stems (stem epidermis, cortex, collenchyma, central cylinder and diameter) and leaves (leaf epidermis upper surface and underside, mesophyll, leaf thickness and bundle sheath thickness).

Both analysed populations of $A$. retroflexus, morphologically characterized by different density of stem hairiness, were found to have a typical structure of herbaceous dicots. The stem had three distinctive zones: epidermis, cortex and central cylinder. Amaranth leaves have dorsoventral structure, i.e. their upper surface and underside can be differentiated. The results indicated high and very high significance of differences found in stem anatomy between the two analysed populations, while leaf anatomy was not found to display significant differences other than in mesophyll thickness.

Keywords: Amaranthus retroflexus L.; Population AMARE; Population AMARE 2 ; Leaf anatomy; Stem anatomy

\section{INTRODUCTION}

The family Amarantaceae includes around 850 species classified into 65 genera (Carlquist, 2003), the genus Amaranthus including about 70 species (Costea and DeMason, 2001). Those are annual, biannial and perennial herbaceous and woody (in tropical regions) plants with erect, perpendicular or lodged stems and simple, entire, alternate or opposite leaves with no stipules. Amaranthus is the single genus of this family rep- 
resented in Serbian flora which includes eight species (Josifović (ed.), 1972). Extensive research has been done to classify these species and assign them to precise suborders and sections. Amaranthus species were initially divided into two sections: Amaranthus and Blitopsis (Carretero, 1979; Hugin, 1986, 1987). However, Mosyakin and Robertson (1996) later grouped those species into 3 suborders and 9 sections based on characteristics of their flowering process and flower morphology. Costea and DeMason (2001) have pointed out the significance of anatomy and morphology studies of Amaranthus leaves and stems in terms of taxonomic differentiation among species of this genus.

Several researchers (Balfour, 1965; Fahn and Zimmermann, 1982; Carlquist, 2003; Hong et al., 2005) have examined the anatomy of Amaranthaceae species, adjusting their examination to the specificities of each species analyzed. Carlquist (2003) examined the anatomy of stem and root of seven species of that family, focusing on studies of the anatomy of stem secondary xylem. Hong et al. (2005) examined leaf anatomy of Amaranthus tricolor $\mathrm{L}$. and chloroplast and mitochondrial ultrastructure related to their physiological functions. Ueno (2001) monitored localization of photosynthetic and photorespiratory enzymes in the epidermis, mesophyll, bundle sheath and vascular tissue of the species Amaranthus viridis L. Tazoe et al. (2006) studied the structure of photosynthetic apparatus in Amaranthus cruentus L. leaves.

Species of the genus Amaranthus are known to demonstrate different reactions to ALS (acetolactate synthase) inhibitors as they share many features (a tendency to mutation and hybridization first of all) possibly related to an evolution of resistance in their populations. This has been confirmed for a great number of amaranth species, such as: Amaranthus palmeri (Gaeddert et al., 1997), $A$. retroflexus (Ferguson et al., 2001), $A$. blitoides (Sibony and Rubin, 2003), A. rudis (Lovell et al., 1996), $A$. hybridus (Maertens et al., 2004) and $A$. powellii (Ferguson et al., 2001). Tardif et al. (2006) attempted to determine a relationship between mutation that causes resistance to herbicides ALS-inhibitors, and morphological and histological characteristics of the species $A$. powellii, but could not identify a distinct connection between the Trp574Leu substitution on the ALS enzyme and plant morphology and anatomy of resistant populations. However, they reported differences in the anatomy of roots, stems and leaves between susceptible and resistant populations. Therefore, anatomical differences among populations of a single spe- cies may be caused by different abiotic (e.g. herbicide application over several successive years) or biotic factors, which may indicate different population susceptibilities to herbicides.

The weed species Amaranthus retroflexus is one of the most widespread and most frequent weeds of arable fields worldwide, and in this country as well (Paul and Elmore, 1984; Vrbničanin and Šinžar, 2003). In Serbia, it is an invading species at present and one listed among economically harmful species (Vrbničanin et al., 2004, 2008). Apart from arable fields, it is also often found at ruderal sites. A. retroflexus has a primary type of stem anatomy typical of herbaceous dicots which includes the epidermis, cortex and central cylinder, while leaf anatomy is dorsoventral (i.e. the upper surface and underside epidermis are different) as in other dicots, and consisting of epidermis, mesophyll, vascular and mechanical tissue (Metcalfe and Chalk,1950).

This study aimed to examine stem and leaf anatomies in two populations of the weed species $A$. retroflexus, pop. AMARE 1 (green stems covered in sparse hairs) and pop. AMARE 2 (green stems, but exceptionally hairy), which may be related to their respective susceptibility or tolerance (resistance) to herbicides.

\section{MATERIAL AND METHODS}

Plants of two $A$. retroflexus populations (pop. $\mathrm{AMARE}_{1}$ - green plants with sparse stem hairs, and pop. AMARE 2 - green plants with pronounced stem hairiness) were sampled at the stage of full vegetative growth (approximately $50-70 \mathrm{~cm}$ in height) from fields of the Zemun Polje Maize Research Institute in 2006. Samples were taken from a number of plants (30-40) in each population and kept in 50\% ethanol solution until permanent microscopic preparations were made. From each plant, a $5 \mathrm{~cm}$ excision was made from the central part of the stem, and two physiologically mature leaves were sampled. Excisions for anatomical cross sections were made from the central part of the leaf. Microscopic preparations were made by stadard paraffin method (Ruzin, 1999). Paraffin molds were cut out with a LEICA SM $2000 \mathrm{R}$ microtome and cross sections $(5-15 \mu \mathrm{m}$ thick) stained with the histological dyes toluidine blue, safranin and alcian blue. Permanent microscopic slides were used to analyze the anatomy of individual organs and measure relevant parameters. In stem cross sections, the examined parameters were: thickness of stem epidermis (Se), diameter of stem cor- 
tex $(\mathrm{Sc})$, thickness of stem collenchyma $(\mathrm{C})$, diameter of central cylinder $(\mathrm{Cc})$ and stem diameter $(\mathrm{Sd})$. Leaf cross section measurements included: height of the leaf upper surface epidermis (Luse) and underside epidermis (Lue), thickness of leaf mesophyll (Lm), leaf thickness (Lt) and thickness of bundle sheaths (Bs). The samples were examined under a light microscope LEICA DMLS, photographed with a digital camera LEICA DC 300, and measurements were done using the LEICA IM 1000 software.

The results were processed by STATISTICA 6.0 software, and the average, minimum and maximum values computed for each parameter, as well as standard error (SE). T-test was used to determine the significance of differences found between the examined populations regarding each of the analyzed parameters.

\section{RESULTS AND DISCUSSION}

\section{Stem anatomy of pop. AMARE 1 and $A M A R E_{2}$}

Stem anatomy of the family Amarantaceae, focusing especially on the anatomy of secondary xylem, was examined by Rajput (2002) on 70 species in 9 genera of that family, while Costea and DeMason (2001) analyzed the taxonomic significance of stem morphology and anatomy of the genus Amaranthus. Secondary thickening of stem in woody representatives of Amaranthaceae is atypical, and secondary stem anatomy differs from that of many other dicotyledonous species (Balfour, 1965; Fahn and Zimmermann, 1982; Viana, 1993). Also, some representatives of this family are particularly interesting in terms of formation of successive cambium and products of its activity (Carlquist, 2003).

Stem cross section shows that the weed species $A$. retroflexus has a typical anatomy of herbaceous dicots, having three distinctive zones: stem epidermis, cortex and central cylinder (Figures 1 and 2). Stem diameter (Sd) differed significantly between the examined amaranth populations, the average being $3484.84 \pm 588.96$ $\mu \mathrm{m}(\min =2704.00 \mu \mathrm{m} ; \max =4540.60 \mu \mathrm{m})$ in pop. $\mathrm{AMARE}_{1}$, and $3874.54 \pm 609.09 \mu \mathrm{m}(\mathrm{min}=2482.80$ $\mu \mathrm{m} ; \max =4662.10 \mu \mathrm{m})$ in pop. $\mathrm{AMARE}_{2}$. The hairy population consequently had thicker stems by an average $389.70 \mu \mathrm{m}$ (Tables 1 and 2). A very significant difference in stem diameters had also been found in $A$. powellii samples of different susceptibilities to herbicides ALS-inhibitors, the susceptible population having basal stem diameters ranging from 5.6 to $7.3 \mathrm{~mm}$, and the resistant population from 2.3 to $3.7 \mathrm{~mm}$ (Tardif et al., 2006).

Stem epidermal (Se) cells form a primary covering tissue which is built from single-layered cells closely packed without intercellular space. Those cells elongate paral-

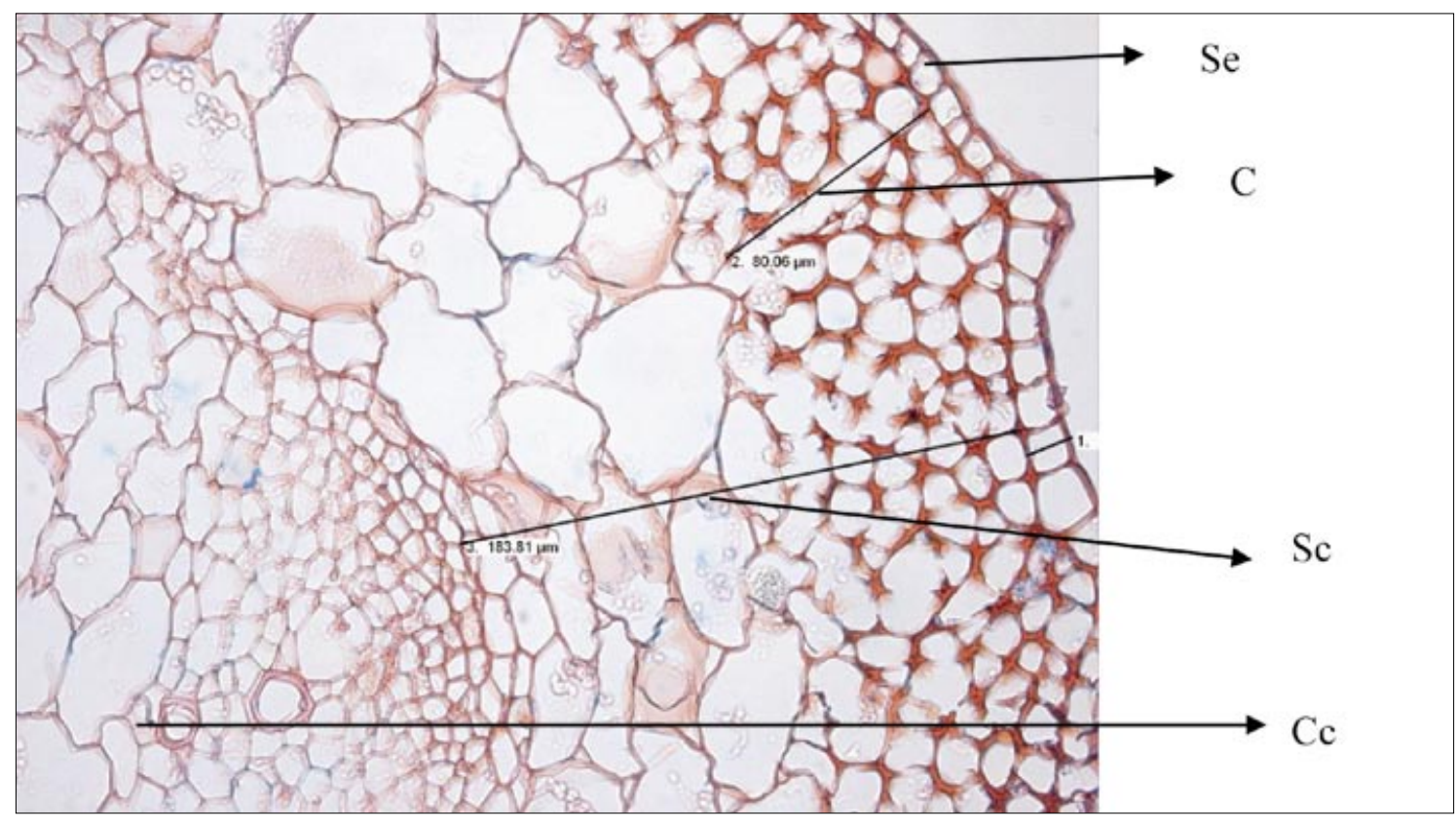

Figure 1. Stem cross section of pop. AMARE 1 (magnification $100 \mathrm{x}$ ) 


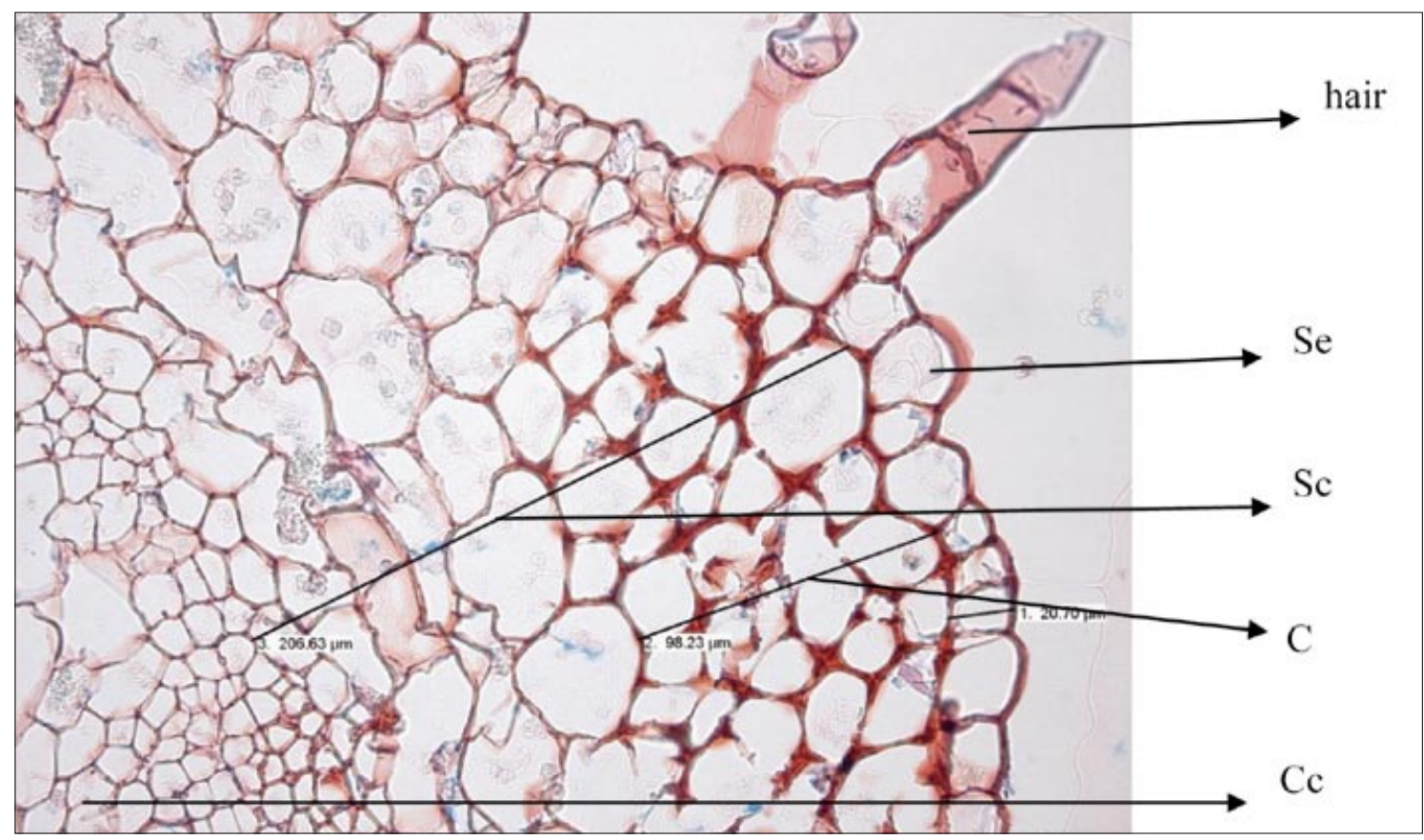

Figure 2. Stem cross section of pop. $\mathrm{AMARE}_{2}$ (magnification 100x)

Table 1. Parameters of stem anatomy in pop. AMARE 1

\begin{tabular}{lccc}
\hline Parameters & Average \pm SE $(\mu \mathrm{m})$ & Minimum $(\mu \mathrm{m})$ & Maximum $(\mu \mathrm{m})$ \\
\hline Stem diameter $(\mathrm{Sd})$ & $3484.84 \pm 588.96$ & 2704.00 & 4540.60 \\
Stem epidermis $(\mathrm{Se})$ & $16.365 \pm 2.65$ & 11.32 & 21.13 \\
Stem cortex $(\mathrm{Sc})$ & $209.54 \pm 49.30$ & 103.55 & 331.33 \\
Collenchyma $(\mathrm{C})$ & $85.00 \pm 18.66$ & 15.14 & 126.01 \\
Central cylinder $(\mathrm{Cc})$ & $3285.93 \pm 537.01$ & 2589.13 & 4188.14 \\
\hline
\end{tabular}

Table 2. Parameters of stem anatomy in pop. $\mathrm{AMARE}_{2}$

\begin{tabular}{lccc}
\hline Parameters & Average \pm SE $(\mu \mathrm{m})$ & Minimum $(\mu \mathrm{m})$ & Maximum $(\mu \mathrm{m})$ \\
\hline Stem diameter $(\mathrm{Sd})$ & $3874.54 \pm 609.09$ & 2482.80 & 4662.10 \\
Stem epidermis $(\mathrm{Se})$ & $19.25 \pm 3.26$ & 14.00 & 26.50 \\
Stem cortex $(\mathrm{Sc})$ & $293.63 \pm 80.03$ & 190.81 & 471.94 \\
Collenchyma $(\mathrm{C})$ & $116.43 \pm 21.99$ & 89.36 & 166.62 \\
Central cylinder $(\mathrm{Cc})$ & $3561.65 \pm 525.80$ & 2277.99 & 4163.66 \\
\hline
\end{tabular}

Table 3. Significance of differences between pop. AMARE ${ }_{1}$ and $A M A R E_{2}$ regarding stem anatomy parameters ( $t$-test)

\begin{tabular}{lcc}
\hline Parameters & $\mathrm{p}$ & $\mathrm{AMARE}_{1}: \mathrm{AMARE}_{2}$ \\
\hline Stem diameter $(\mathrm{Sd})$ & 0.0210000 & $*$ \\
Stem epidermis $(\mathrm{Se})$ & 0.0000344 & $*$ \\
Stem cortex $(\mathrm{Sc})$ & 0.0000170 & ${ }^{*}$ \\
Stem cortex collenchyma $(\mathrm{C})$ & 0.0000006 & $*$ \\
\hline
\end{tabular}

$\mathrm{p}<0.01\left(^{* *}\right)-$ very significant statistical difference

$0.01<\mathrm{p}<0.05\left(^{*}\right)-$ significant statistical difference 
lel to the stem, and are mostly polygonal with approximately the same lengths and widths. Depending on environmental conditions, the epidermal surface may include a cuticle of variable thickness (Pekić Quarrie and Rančić, 2007). Costea and DeMason (2001) stressed that the conformation of Amaranthus Se cells was not uniform. In the stomatal area, those cells were found to be more or less isodiametric, with chloroplasts included and thinner cell walls, but the remaining cells were heterodiametric, smaller and with thicker cell walls. In our pop. AMARE 1 , the average Se thickness was $16.36 \pm 2.65 \mu \mathrm{m}(\min =11.32 \mu \mathrm{m} ; \max =21.13$ $\mu \mathrm{m})$ (Table 1), while the thickness of primary covering tissue (i.e. Se) of pop. AMARE 2 was $19.25 \pm 3.26 \mu \mathrm{m}$ $(\min =14.00 \mu \mathrm{m} ; \max =26.50 \mu \mathrm{m})$. Therefore, the hairy population of $A$. retroflexus had thicker stem epidermis by approximately $2 \mu \mathrm{m}$ (Table 2 ).

Stem cortex (Sc) of $A$. retroflexus is built of collenchyma (C) and cortex parenchyma cells. Collenchyma consists of several cellular layers beneath the epidermis with thickened tangential walls and Sc ending in a starch layer (Pekić Quarrie and Rančić, 2007). In pop. $A M A R E_{1}$, the average cortex thickness was $209.54 \mu \mathrm{m}(\min =103.55 \mu \mathrm{m}$; $\max =331.13 \mu \mathrm{m})$ (Table 1), while collenchyma average thickness was 85.00 $\pm 18.66 \mu \mathrm{m}(\min =15.14 \mu \mathrm{m} ; \max =126.01 \mu \mathrm{m})$, meaning that cortext parenchyma (the difference between cortex and collenchyma layers) in that population was $2.5 \mathrm{x}$ thicker than the collenchyma. In pop. $\mathrm{AMARE}_{2}$, cortex was thicker (as was Se) in the hairy population of $A$. retroflexus, and its average thickness was $293.63 \mu \mathrm{m}(\min =190.81 \mu \mathrm{m}$; $\max =471.94 \mu \mathrm{m})$ (Table 2). Collenchyma thickness in pop. $\mathrm{AMARE}_{2}$ was $116.43 \pm 21.99 \mu \mathrm{m}(\min =89.36 \mu \mathrm{m} ; \max =166.62$ $\mu \mathrm{m})$ on the average, and thicker in the hairy population of $A$. retroflexus than in the green plants with sparse hairs. Furthermore, cortex parenchyma was again in this population significantly thicker (approximately $2.5 \mathrm{x}$ ) than the collenchyma layer. Cortex thickness in $A$. powellii plants susceptible to ALS inhibitors had been found to vary from 372 to $421 \mu \mathrm{m}$, while it ranged from 208 to $321 \mu \mathrm{m}$ in a resistant population (Tardif et al., 2006).

Central cylinder $(\mathrm{Cc})$ is at the stem centre and begins with pericycle. In dicot stem central cylinders, collateral open bundles can be observed in most cases (Metcalfe and Chalk, 1965). However, the examined stem cross sections of $A$. retroflexus were found to have collateral bundles of a closed type, which is consistent with Gibons (1994), who found the primary vascular system of amaranths to be of a closed type. Kocacinar and Sage (2003) examined the xylem structure and functioning of $\mathrm{C}_{4}$ plants, finding that in arid regions those plants (including the species $A$. retroflexus) have more developed xylems, which helps plants survive water-deficient conditions. The cross section anaysis showed that central cylinder thickness in our pop. AMARE 1 population was $3285.93 \pm 537.01 \mu \mathrm{m}$ $(\min =2589.13 \mu \mathrm{m} ; \max =4188.14 \mu \mathrm{m})$. Similar to the other stem parameters measured, $\mathrm{Cc}$ was thicker in pop. $\mathrm{AMARE}_{2}$ than in pop. AMARE $E_{1}$, the average thickness being $3561.65 \pm 525.80 \mu \mathrm{m}(\mathrm{min}=2589.13 \mu \mathrm{m}$; $\max$ $=4188.14 \mu \mathrm{m})$ (Tables 1 and 2$)$. Comparing the $A$.powellii populations of different susceptibilities to herbicides ALS-inhibitors, central cylinders were found to be more developed in susceptible (4.8-6.3 $\mathrm{mm}$ diameter) than in resistant plants (1.9-3.1 mm diameter) (Tardif et al., 2006).

Statistical processing of data ( $\mathrm{t}$-test) confirmed significant and very significant differences among the stem anatomy parameters measured in pop. AMARE $E_{1}$ and $\mathrm{AMARE}_{2}$ (Table 3). The two populations differed very significantly regarding stem epidermis and cortex collenchyma $(\mathrm{p}<0.01)$, while differences between stem diameter and cortex thickness had a significance exceeding 0.01 , but below 0.05 .

\section{Leaf anatomy of pop. AMARE 1 and $\mathrm{AMARE}_{2}$}

The leaf of $A$. retroflexus has been an object of many studies of structure and physiology of $\mathrm{C}_{4}$ plants with a special focus on: leaf epidermis and mesophyll anatomy; vascular structure; phloem within that structure; plasmodesma frequency; chloroplast polymorphism; anatomy of endoplasmatic reticulum and its relation to chloroplast, mitochondrion and organelle membranes; the relationship between chloroplast or other organelle structures with photosynthetic processes; $\mathrm{CO}_{2}$ fixation processes, etc. (Tregunna and Downton, 1967; Black and Mollenhauer, 1971; Usuda et al., 1971; Fisher and Evert, 1982a, 1982b, 1982c, 1982d). Leaves of the weed species $A$. retroflexus have a dorsoventral anatomy, i.e. different epidermal upper surface and underside. As in most terrestrial dicots, leaf cross section reveals well-differentiated: leaf upper surface epidermis (Luse), leaf underside epidermis (Lue) and leaf mesophyll $(\mathrm{Lm})$ with collateral closed bundle sheaths (Figures 3 and 5). In mesophyll, palisade tissue is turned towards leaf upper surface epidermis, while spongy tissue is turned towards leaf underside epidermis (Pekić 


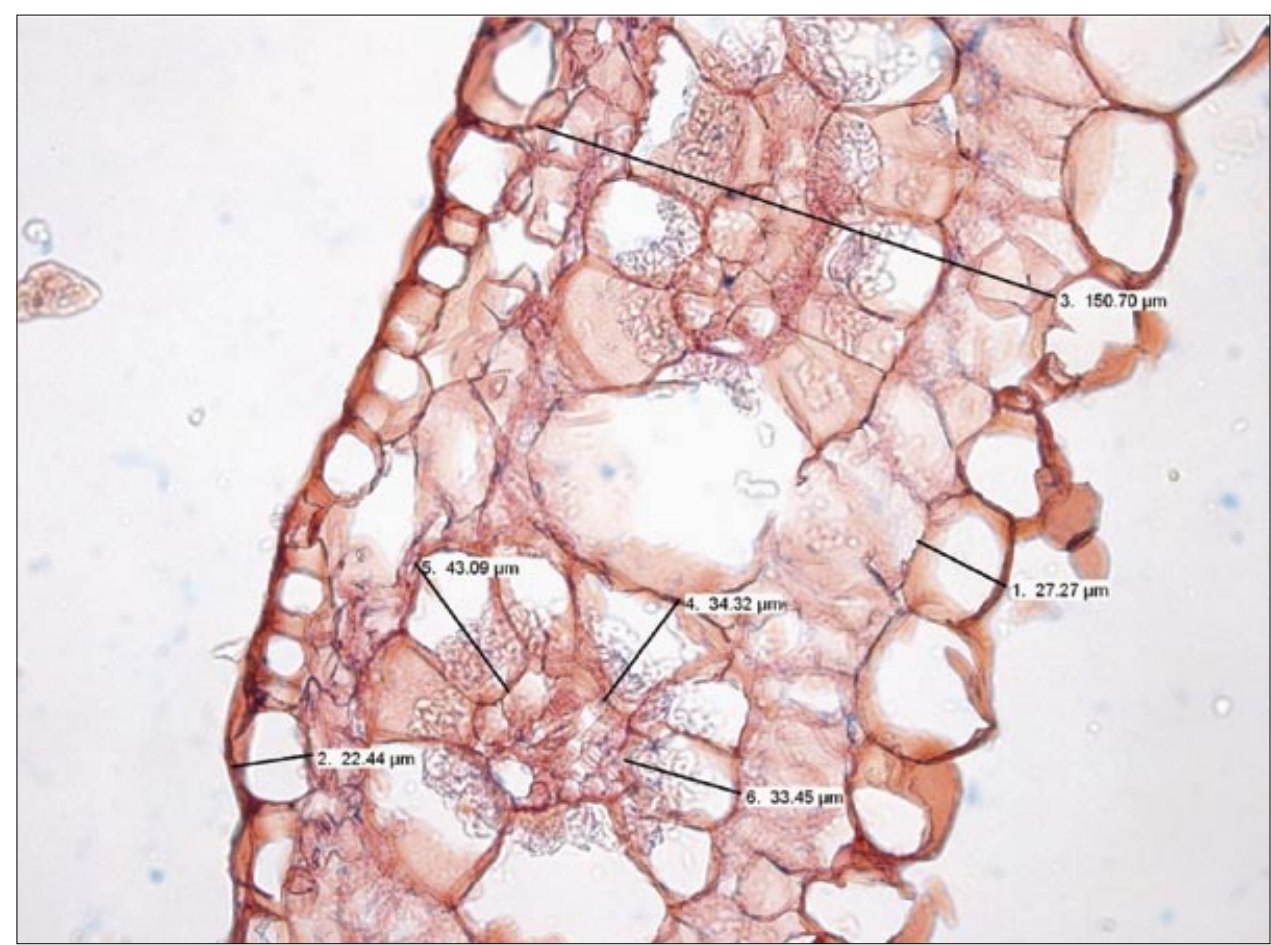

Figure 3. Leaf cross section of pop. AMARE 1 (magnification 200x)

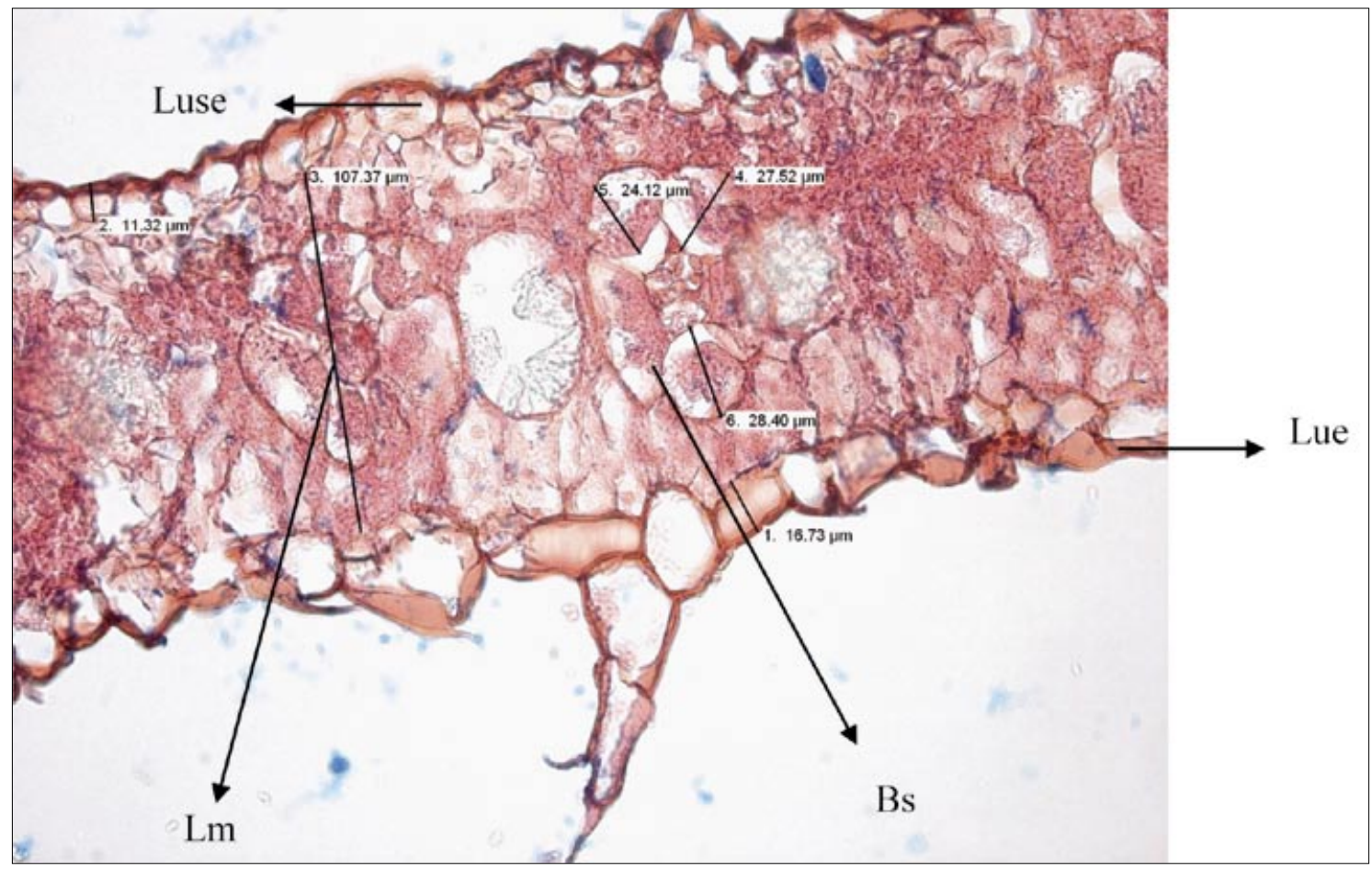

Figure 4. Leaf cross section of pop. AMARE $_{2}$ (magnification 200x) 
Table 4. Leaf anatomy parameters in pop. $\mathrm{AMARE}_{1}$

\begin{tabular}{lccc}
\hline Parameters & Average \pm SE $(\mu \mathrm{m})$ & Minimum $(\mu \mathrm{m})$ & Maximum $(\mu \mathrm{m})$ \\
\hline Leaf thickness $(\mathrm{Lt})$ & $195.48 \pm 30.73$ & 141.04 & 273.94 \\
Leaf upper surface epidermis (Luse) & $22.90 \pm 5.84$ & 13.66 & 47.34 \\
Leaf underside epidermis (Lue) & $19.78 \pm 4.92$ & 11.58 & 38.17 \\
Leaf mesophyll $(\mathrm{Lm})$ & $146.44 \pm 19.97$ & 115.80 & 188.43 \\
Bundle sheaths $(\mathrm{Bs})$ & $33.12 \pm 6.13$ & 16.74 & 50.69 \\
\hline
\end{tabular}

Table 5. Leaf anatomy parameters in pop. AMARE 2

\begin{tabular}{lccc}
\hline Parameters & Average \pm SE $(\mu \mathrm{m})$ & Minimum $(\mu \mathrm{m})$ & Maximum $(\mu \mathrm{m})$ \\
\hline Leaf thickness $(\mathrm{Lt})$ & $205.22 \pm 39.64$ & 129.86 & 285.08 \\
Leaf upper surface epidermis (Luse) & $24.32 \pm 5.52$ & 12.47 & 41.18 \\
Leaf underside epidermis (Lue) & $19.62 \pm 5.15$ & 10.44 & 29.49 \\
Leaf mesophyll $(\mathrm{Lm})$ & $161.31 \pm 28.97$ & 106.95 & 214.41 \\
Bundle sheaths $(\mathrm{Bs})$ & $34.65 \pm 6.45$ & 21.35 & 54.03 \\
\hline
\end{tabular}

Table 6. Significance of differences between pop. $A M A R E_{1}$ and $A M A R E_{2}$ regarding leaf anatomy parameters (t-test)

\begin{tabular}{lcc}
\hline Parameters & $\mathrm{p}$ & AMARE $_{1}:$ AMARE $_{2}$ \\
\hline Leaf upper surface epidermis (Luse) & 2,240 & $\mathrm{NS}$ \\
Leaf underside epidermis (Lue) & 0,890 & $\mathrm{NS}$ \\
Leaf mesophyll (Lm) & 0,012 & $*$ \\
Bundle sheath s (Bs) & 0,060 & $\mathrm{NS}$ \\
\hline
\end{tabular}

$\mathrm{p}<0.01\left({ }^{* *}\right)-$ very significant statistical difference

$0.01<\mathrm{p}<0.05\left(^{*}\right)$ - significant statistical difference

$\mathrm{p}>0.05$ (NS) - no statistically significant difference

Quarrie and Rančić, 2007). Our leaf cross sections revealed that $\mathrm{AMARE}_{2}$ had thicker leaves $(205.22 \pm 39.64$ $\mu \mathrm{m} ; \min =129.86 \mu \mathrm{m}$ and $\max =285.08 \mu \mathrm{m})$ than pop. $\operatorname{AMARE}_{1}(195.48 \pm 30,73 \mu \mathrm{m} ; \mathrm{min}=141.04 \mu \mathrm{m}$ and $\max =273.94 \mu \mathrm{m})($ Tables 4 and 5$)$.

Leaf epidermis of $A$. retroflexus is mostly built of polygonal epidermal cells with sinuate walls and wellformed cuticles on peripheral cell walls, which are closely packed without intercellular space. Fisher and Evert (1982d) noticed that both types of epidermis of that species contain pairs of stomatal cells that are dissociated from auxiliary cells of the stoma complex. Data from our cross section measurements of both $A$. retroflexus populations indicate that pop. AMARE 2 had thicker upper surface epidermis (Luse) (24.32 \pm 5.52 $\mu \mathrm{m} ; \min =12.47 \mu \mathrm{m}$ and $\max =47.34 \mu \mathrm{m})$ than pop. AMARE $_{1}(22.90 \pm 5.84 \mu \mathrm{m} ; \min =13.66 \mu \mathrm{m}$ and $\max =47.34 \mu \mathrm{m})$. The average Luse follows the same pattern observed in stem anatomy and total leaf thickness, where pop. $\mathrm{AMARE}_{2}$ demonstrated higher values (Tables 4 and 5). In contrast to the Luse parameter, pop. $A M A R E_{1}$ and $A M A R E_{2}$ were not found to differ regarding the height of epidermal cells of leaf undersides
(Lue). In pop. AMARE ${ }_{1}$, the average height of Lue was $19.78 \pm 4.92(\min =11.58 \mu \mathrm{m}$ and $\max =38.17 \mu \mathrm{m})$, and in pop. $\mathrm{AMARE}_{2}$ it was $19.62 \pm 5.15 \mu \mathrm{m}(\mathrm{min}=10.44$ $\mu \mathrm{m}$ and $\max =29.49 \mu \mathrm{m}$ ). Conversely, Fisher and Evert (1982a) found Luse cell to be smaller than Lue cells in A. retroflexus plants.

Mesophyll $(\mathrm{Lm})$ is a tissue filling the leaf interior between epidermal upper surface and underside. Most cells of this layer in $A$. retroflexus plants have a radial arrangement around bundle sheaths and a direct connection to them (Fisher and Evert, 1982a). Although mesophyll can be differentiated as either palisade or spong tissue, in this study we measured only its overall thickness. The data showed that $\mathrm{Lm}$ was more developed in pop. $A M A R E_{2}$ than in pop. $A M A R E_{1}$. Pop. AMARE had an average mesophyll thickness of $146.44 \pm 19.97$ $\mu \mathrm{m}(\min =115.80 \mu \mathrm{m}$ and $\max =188.43 \mu \mathrm{m})$, and pop. AMARE $_{2} 161.31 \pm 28.97 \mu \mathrm{m}(\mathrm{min}=106.95 \mu \mathrm{m}$ and $\max =214.41 \mu \mathrm{m})$. Therefore, leaf mesophyll of the hairy amaranth population was by $14.87 \mu \mathrm{m}$ thicker, which is consistent with our previous finding of total leaf thickness being greater in pop. AMARE 2 than in pop. AMARE ${ }_{1}$ (Tables 4 and 5). Differences in mes- 
ophyll thickness between $A$. powellii populations resistant or susceptible to herbicides ALS-inhibitors have been reported by Tardif et al. (2006). They found leaves of the resistant population of $A$. powellii to be considerably thicker.

As $A$. retroflexus belongs to $\mathrm{C}_{4}$ plants, in this study we also examined bundle sheath (Bs) cells. They are highly developed and have an important physiological function, being directly associated with the more active photosynthetic process and greater photo-net production of this group of plants. The $\mathrm{C}_{4}$ type of photosynthesis defines the way in which $\mathrm{CO}_{2}$ accumulates in chloroplasts at a reduction cycle site. It reflects an evolving adaptation of plants in warm and dry regions by which photorespiration is reduced and leads to a significantly higher productivity of this group of plants (Nešković et al., 2003; Hong et al., 2005). Measurement data show that bundle sheaths in pop. AMARE $\mathrm{A}_{2}$ were slightly more developed $(34.65 \pm 6.45 \mu \mathrm{m} ; \mathrm{min}=21.35 \mu \mathrm{m}$ and $\max =54.03 \mu \mathrm{m})$ than pop. $\mathrm{AMARE}_{1}(33.12 \pm 6.13$ $\mu \mathrm{m} ; \min =16.74 \mu \mathrm{m}$ and $\max =50.69 \mu \mathrm{m})$. Examining A. powellii, Tardif et al. (2006) found that its populations resistant to herbicides ALS-inhibitors had thicker tertiary nerves than susceptible populations, where Bs thickness varied between 34 and $38 \mu \mathrm{m}$, while bundles in the resistant populations were thicker only at the edges $(36-40 \mu \mathrm{m})$.

Statistical processing of data ( $\mathrm{t}$-test) on the measured leaf anatomy parameters displayed a significant difference $(0.01<p>0.05)$ between pop. AMARE $E_{1}$ and $\mathrm{AMARE}_{2}$ only for leaf mesophyll (Table 6). In contrast to the stem anatomy, which revealed significant or very significant statistical differences for all parameters measured, mesophyll thickness was the only such parameter of the leaf (Tables 3 and 6).

The results of this study indicate that, apart from differences in hairiness, pop. AMARE ${ }_{1}$ and $\mathrm{AMARE}_{2}$ differed also in the anatomy of their stems (stem diameter, epidermis thickness, cortex diameter, collenchyma thickness and central cylinder diameter), while differences in leaf anatomy were detected only for mesophyll thickness. Such differences between populations $\mathrm{AMARE}_{1}$ and $\mathrm{AMARE}_{2}$ provide a basis for our better understanding plant reactions in terms of herbicide uptake and translocation that are potentially connected to an evolution of resistance of $A$. retroflexus populations to herbicides in the territory of Serbia (at Zemun Polje locality).

\section{ACKNOWLEDGEMENT}

This study was conducted as part of a project titled „Biological, chemical, toxicological and ecotoxicological studies of herbicides and their application" (TR20041), financed by the Ministry of Science and Technological Development of the Republic of Serbia.

\section{REFERENCES}

Balfour, E.N.A.: Anomalous secondary thickening in Chenopodiaceae, Nyctaginaceae and Amarantaceae. Phytomorphology,15: 111-122, 1965.

Black, C.C. and Mollenhauer, H.H.: Structure and distribution of chloroplasts and other organelles in leaves with various rates of photosynthesis. Plant Physiology, 47: 15-23, 1971.

Carlquist, S.: Wood and stem anatomy of woody Amaranthaceae s.s.: ecology, systematics and problems of defining rays in dicotyledons. Botanical Journal of the Linnean Society, 143: 1-19, 2003.

Carretero, J.L.: El genero Amaranthus en Espana. Collect. Bot. (Barselona), 11: 105-142, 1979.

Costea, M. and DeMason, D.: Stem morphology and anatomy in Amaranthus L. (Amaranthaceae) - Taxonomic significance. Journal of Torrey Botanical Society, 128(3): 254281, 2001.

Fahn, A. and Zimmermann, M.H.: Development of successive cambia in Atriplex halimus (Chenopodiaceae). Botanical Gazette, 143: 353-357, 1982.

Ferguson, G.M., Hamill, A.S. and Tardif, F.J.: ALS inhibitor resistance in populations of Powell amaranth and redroot pigweed. Weed Science, 49: 448-453, 2001.

Fisher, D.G. and Evert, R.F.: Studies on the leaf of Amaranthus retroflexus (Amaranthaceae): Morphology and anatomy. American Journal of Botany, 69(7): 1133-1147, 1982a.

Fisher, D.G. and Evert, R.F.: Studies on the leaf of Amaranthus retroflexus (Amaranthaceae): quantitative aspects, and solute concentration in the phloem. American Journal of Botany, 69(9): 1375-1388, 1982b.

Fisher, D.G. and Evert, R.F.: Studies on the leaf of Amaranthus retroflexus (Amaranthaceae): ultrastructure, plasmodesmatal frequency, and solute concentration in relation to phloem loading. Planta, 155: 377-387, 1982c.

Fisher, D.G. and Evert, R.F.: Studies on the leaf of Amaranthus retroflexus (Amaranthaceae): Chloroplast polymorphism. Botanical Gazette, 143(2): 146-155, 1982d. 
Gaeddert,J.W., Peterson, D.E. and Horak, M.J.: Control and cross-resistance of an acetolactate synthase inhibitorResistant palmer amaranth (Amaranthus palmeri) Biotype. Weed Technology, 11: 132-137, 1997.

Gibson, A.C.: Vascular tissues. In: Caryophyllales: Evolution and Systematics (Behnke, H.-D. and Marby, T.J., eds.). Springer Verlag, Berlin, 1994, pp. 45-74.

Hong,J., Jiang, D.-A., Weng, X.-Y., Wang, W.-B., and Hu, D.-W.: Leaf anatomy, chloroplast ultrastructure, and cellular localisation of ribulose-1,5-bisphosphate carboxylase/oxygenase (RuBPCO) and RuBPCO activase in Amaranthus tricolor L., Photosynthetica, 43(4): 519-528, 2005.

Hugin, G.: Die Verbeitung von Amaranthus-Arten in der sudlichen und mittieren Oberheinebene sowie eingen angrenzenden Gebieten. Phytocoenologia, 14: 289-379, 1986.

Hugin, G.: Einige Bemerkungen zu wenig bekannten Amaranthus-Sippen (Amaranthaceae) Mitteleuropas. Willdenowia, 16: 453-478, 1987.

Josifović, M. (ed.): Flora SR Srbije. Tom III, SANU, Beograd, 1972, str. 1-10.

Kocacinar, F. and Sage, R.F.: Photosynthetic pathway alters xylem structure and hydraulic function in herbaceous plants. Plant Cell and Environment, 26: 2015-2026, 2003.

Lovell, S.T., Wax, L.M., Horak, M.J. and Peterson, D.E.: Imidazolinone and Sulfonylurea Resistance in a Biotype of Common Waterhemp. Weed Science, 44: 789-794, 1996.

Maertens, K.D., Sprague, C.L., Tranel, P.J. and Hines, R.A.: Amaranthus hybridus populations resistant to triazine and acetolactate synthase-inhibiting herbicides. Weed Research, 44: 21-26, 2004.

Metcalfe, C.R. and Chalk, L.: Anatomy of the dicotyledons. 2 vols. Oxford.: Clarendon Press, 1965.

Mosyakin, S.L. and Robertson, K.R.: New infrageneric taxa and combinations in Amaranthus (Amarantaceae). Annals Botany Fennici, 33: 275-281, 1996.

Nešković, M., Konjević, R. i Ćulafić, Lj.: Fiziologija biljaka. NNK-International, Beograd, 2003.

Paul, R.N. and Elmore, C.D.: Weeds and $\mathrm{C}_{4}$ syndrome. Weeds Today, 15: 3-4, 1984.

Pekić Quarrie, S. i Rančić, D.: Anatomija gajenih biljaka. Poljoprivredni fakultet, Beograd, 2007.

Rajput, K.S.: Stem anatomy of Amaranthaceae: Rayless nature of xylem. Flora, 197: 224-232, 2002.
Ruzin, S.E.: Plant Microtechnique and Microscopy. Oxford University Press, New York, London, 1999.

Sibony, M. and Rubin, B.: The ecological fitness of ALSresistant Amaranthus retroflexus and multiple-resistant Amaranthus blitoides. Weed Research, 43: 40-47, 2003.

Tardif F., Rajcan, I. and Costea, M.: A mutation in herbicide target site acetohydroxyacid synthase produces morphological and structural alterations and reduces fitness in Amaranthus powellii. New Phytologist, 169: 251-264, 2006.

Tazoe, Y., Noguchi, K.O. and Terashima, I.: Effect of growth and nitrogen nutrition on the organization of the photosynthetic apparatus in leaves of a $\mathrm{C}_{4}$ plant, Amaranthus cruentus. Plant Cell and Environment, 29: 691-700, 2006.

Tregunna, E.B. and Downton, J.: Carbon dioxide compensation in members of the Amaranthaceae and some related families. Canadian Journal of Botany, 45: 2385-2387, 1967.

Ueno, $\boldsymbol{O}$.: Ultrastructural localization of photosynthetic and photorespiratory enzymes in epidermal, mesophyll, bundle sheat, and vascular bundle cells of the $\mathrm{C}_{4} \operatorname{dicot}$ Amaranthus viridis. Journal of Experimental Botany, 52(358): 1003-1013, 2001.

Usuda, H., Kanai, R. and Takeuchi, M.: Comparison of carbon dioxide fixation and the fine structure in various assimilatory tissues of Amaranthus retroflexus L. Plant Cell Physiology, 12: 917-930, 1971.

Viana, $V$ : Contribuicao ao estudo anatomico do eixo vegetativo de Amaranthus viridis L. Arquivos Jardium Botanico Rio de janeiro, 31: 15-70, 1993.

Vrbničanin, S., Karadžić, B. i Dajić Stevanović, Z.: Adventivne i invazivne korovske vrste na području Srbije. Acta herbologica, 13(1): 1-13, 2004.

Vrbničanin, S., Malidža, G., Stefanović, L., Elezović, I., Stanković-Kalezić, R., Marisavljević, D., RadovanovJovanović, K., Pavlović, D. i Gavrić, M.: Distribucija nekih ekonomski štetnih, invazivnih i karantinskih korovskih vrsta na području Srbije. I deo: Prostorna distribucija i zastupljenost osam korovskih vrsta na području Srbije. Biljni lekar, XXXVI(5): 303-313, 2008.

Vrbničanin, S. i Šinžar, B.: Elementi herbologije sa praktikumom. Poljoprivredni fakultet i Zavet, Beograd, 2003. 


\section{Uporedna analiza anatomske građe dve populacije štira (Amaranthus retroflexus L.)}

\section{REZIME}

U ovom radu je proučavana anatomska građa stabla i lista dve populacije korovske vrste Amaranthus retroflexus L. (štir) (pop. AMARE $E_{1}$ sa zelenim stablom prepokrivenim retkim dlakama, i pop. AMARE 2 takođe sa zelenim ali izrazito maljavim stablom) u cilju boljeg razumevanja usvajanja i translokacije herbicida što može biti u vezi sa odgovorima na razvoj rezistetnosti ove vrste na herbicide. Za ispitivanje anatomske građe stabla i lista ove dve populacije (AMARE i AMARE $_{2}$ ) uzorci su sakupljeni sa proizvodnih površina Instituta za kukuruz Zemun Polje tokom 2006. godine. Uzorkovanje materijala je rađeno u fazi punog vegetativnog porasta biljaka. Pravljeni su trajni mikroskopski preparati na kojima su mereni i analizirani elementi anatomske građe stabla (epidermis stabla, primarna kora stabla, kolenhim, centralni cilindar i prečnik stabla) i anatomske građe lista (epidermis lica i naličja lista, mezofil, debljina lista i debljina ćelija omotača provodnog snopića).

Kod obe analizirane populacije A. retroflexus, koje su se morfološki razlikovale po maljavosti (AMARE $E_{1}$ pop. je zelenog stabla prepokrivenog retkim dlakama, a $A_{M A R E_{2}}$ pop. je takođe zelenog stabla sa izraženom maljavošću), konstatovano je da imaju tipičnu građu zeljastih dikotila. Dakle, stablo ima jasno izdiferencirane tri zone: epidermis stabla, primarnu koru i centralni cilindar. List štira je dorzoventralne građe, što znači da se razlikuje epidermis lica i naličje lista. Dobijeni rezultati ukazuju da se građa stabla dve ispitivane populacije štira statistički značajno ili veoma značajano razlikuje u odnosu na sve analizirane parametre, dok na nivou anatomske građe lista nisu konstatovane značajne razlike, sem u debljini mezofila.

Ključne reči: Amaranthus retroflexus L.; pop. AMARE; pop. AMARE ${ }_{2}$; anatomska građa lista; anatomska građa stabla 